Creative Commons User License: CC BY-NC-ND

Abstracted by: EBSCOhost, Electronic Journals Service (EJS),

Google Scholar, Journal Seek, Scientific Commons,

Food and Agricultural Organization (FAO), CABI and Scopus

http://eoi.citefactor.org/10.11226/v26i1
Journal of Agricultural Extension

Vol. 26 (1) January, 2022

ISSN(e): 24086851; ISSN(Print); 1119944X

http://journal.aesonnigeria.org

http://www.ajol.info/index.php/jae

Email: editorinchief@aesonnigeria.org

\title{
Sustainability Likelihood of Community and Social Development Projects in Oyo and Ekiti States, Nigeria \\ https://dx.doi.org/10.4314/jae.v26i1.10
}

\section{Obar, Eucharia E.}

Department of Agricultural Extension and Rural Development, University of Ibadan, Nigeria

E-mail: ukayobar28@gmail.com; Phone:+2348037152693

\section{Adekoya, Adegbenga $\mathrm{E}$}

Department of Agricultural Extension and Rural Development, University of Ibadan, Nigeria

E-mail: vichenfel2@gmail.com ; Phone: +2348038209063

\begin{abstract}
This study investigated the gender and generational involvement of community members on the sustainability likelihood of the Community and Social Development Project (CSDP) in Oyo and Ekiti states, Nigeria. A multistage sampling procedure was used to select 130 respondents (16 youth, 42 adult male, 34 adult female and 38 elders). Focus group discussion was used to collect data. Thematic analysis was used to analyse the data. Respondents indicated their involvement in project phases: needs assessment (2:54, 6:5, 5:1), funding (2:23), decision making (12:4, 9:2, 7:2, 2:30), formulation of Community Development Plan (5:8, 3:3, 35:1), training $(3: 2,6: 6)$ and implementation $(5: 2,2: 25,3: 6,9: 3)$. None of the projects were insured (11:5, 2:26, 19:4), maintenance committee was set in place (8:32, 2:41), projects were relevant (19:7, 6:12, 20:10) and environmental impact assessment was carried out $(7: 8,2: 46,3: 13,1: 34)$. The facilitators of CSDP should monitor the activities of community members and ensure that the community members comply with the activities required for the implementation of the projects as stated in the CSDP implementation manual.
\end{abstract}

Keywords: Community involvement, sustainability likelihood, community and social development project

\section{Introduction}

The paradigm shift from the top-down approach to the bottom-up approach in community development necessitates the involvement of target beneficiaries to have some control over the decisions made during the project cycle. This is important to ensure the ownership of the project and thus the continuous flow of the benefits of the project after its implementation. Consequently, the Community and Social Development Project (CSDP) makes effort to ensure that interventions are grassroots-based and with grassroots participation. Furthermore, the CSDP is a notable partner in infrastructural provisions among communities in Nigeria. It is a 
Creative Commons User License: CC BY-NC-ND

Abstracted by: EBSCOhost, Electronic Journals Service (EJS),

Google Scholar, Journal Seek, Scientific Commons,

Food and Agricultural Organization (FAO), CABI and Scopus
Journal of Agricultural Extension

Vol. 26 (1) January, 2022

ISSN(e): 24086851; ISSN(Print); 1119944X

http://journal.aesonnigeria.org

http://www.ajol.info/index.php/jae

Email: editorinchief@aesonnigeria.org

World Bank assisted projects that aims at enhancing the access of community members to infrastructural facilities. This is achieved through communities' contribution (cash and kind) and holding community meetings to make decisions on what is to be done and how it would be done. However, the composition of community members involved can be questioned. Cobbinah (2015) establish that the involvement of young men and women in development activities has been hindered based on the intimidation and threats by elders which consequently hampers effective involvement and scare those who may wish to be involved in the future. Therefore, the elders and men constitute the hegemonic class in community development activities. Hence, a community project that is not all involving simply becomes not all satisfying. The non-inclusion of generational structure during the project phases will simply imply that infrastructural focus maybe mainly directed towards adult-perceived community needs which may therefore alienate younger generations which will then have an important stake on project sustainability.

The attainment of sustainability is a futuristic endeavor and therefore necessitates the involvement of generations especially the younger generation. When the younger generation is not carried along in community development activities, infrastructure that is supposed to be enduring will be easily abandoned, neglected and quickly dilapidate. Additionally, it is during the implementation of the project that the culture of maintenance is inculcated into the generational units and when the younger generation is not present, there become lapses in sustainability since they represent the future. Furthermore, the energy of the community resides with the younger generations and thus when they are not carried along; it would affect the maintenance of community infrastructure for future use.

Projects that seem to be transformative can become supportive of the current discriminatory practice of women and youth therefore reinforcing and promoting the hegemonic class of men and elders in community development activities. Additionally, in order to increase women's involvement in CDD programmes, a certain percentage of women's involvement was stipulated by World Bank (Wong, 2018). However, the involvement of women can still be faked as the decisions of women can be influenced by their husbands, brothers and fathers (Anderson, 2019). Furthermore, it is more difficult involving young generation in community development because most of them would rather partake in activities that generate income while some of the elders may become too frail to participate in community development activities. For these reasons, satisfaction of all becomes an illusion and sustainability is compromised. CSDP proffers the gender and generational inclusive rule and emphasizes $30 \%$ inclusion of women in the committee

Involvement of community members in the development process has been identified as a strategy that promotes sustainable development but in reality, it has produced power hierarchies in the community (Rouhani, 2017) particularly between men and women and/or between the youth and elders. Consequently, this has limited the 
potential for advancing gender and generational equality and has further widened the gap between the powerful and the less powerful in the community. Therefore, the question of concern should not be if community members are involved in CSDP; rather, the question should be who is being involved in CSDP - which set of community members are having their voices heard and which members make decisions about the community.

In spite of the fact that there are efforts to ensure gender and generational inclusion in CSDP, especially as provisioned in the CSDP implementing manual, there is dearth of information on the approach's procedure employed, assessment and evaluation and the consequences on the sustainability of CSDP. It is against this background that the study was carried out to give answers to the following questions:

1. What is the involvement of community members in CSDP across the project phases by gender and generation?

2. What is the sustainability likelihood of CSDP (economic, technical, social and environmental sustainability)?

\section{Methodology}

The study was carried out in South-west geopolitical zone of Nigeria. The Southwest geopolitical zone is made up of six (6) states namely; Lagos, Ekiti, Ondo, Oyo, Osun and Ogun States. The area lies between longitude $2^{0} 3^{1}$ and $6^{0} 00^{1}$ East and latitude $6^{0} 21^{1}$ and $8^{0} 37^{1}$ North with a total land area of $77,818 \mathrm{~km}^{2}$. The population of the study includes all community members that are beneficiaries of CSDP and all the officials of CSDA in South-western Nigeria.

Four stage sampling procedure was employed in this study. Firstly, $50 \%$ of states participating (Osun, Ondo, Ekiti and Oyo states) in CSDP in South-western Nigeria were randomly selected to give Oyo and Ekiti States. Thereafter, four local government areas (LGAs) and five communities in Oyo State; and five LGAs and five communities in Ekiti State were purposively selected based on the availability of completed CSDP micro-projects 2016-2018. This was followed by the use of random sampling technique to select sixty percent and forty percent of communities in Oyo and Ekiti States, respectively, to give a total of 130 respondents (16 youths, 42 adult males, 34 adult females and 38 elders). In each community, four (4) Focus group discussions made up of youth group, adult male group, adult female group and elderly group were conducted in Oyo and Ekiti States in accordance to the already laid down group used by CSDA.

For the purpose of the in-depth interview (IDI), the Project Officer in charge of gender and vulnerability issues was interviewed while the Project Officer in charge of Information, education, communication and training was interviewed in Ekiti and Oyo states, respectively. Involvement of community members was ascertained based on 
Creative Commons User License: CC BY-NC-ND

Abstracted by: EBSCOhost, Electronic Journals Service (EJS),

Google Scholar, Journal Seek, Scientific Commons,

Food and Agricultural Organization (FAO), CABI and Scopus

http://eoi.citefactor.org/10.11226/v26i1
Journal of Agricultural Extension

Vol. 26 (1) January, 2022

ISSN(e): 24086851; ISSN(Print); 1119944X

http://journal.aesonnigeria.org

http://www.ajol.info/index.php/jae

Email: editorinchief@aesonnigeria.org

the areas of needs assessment; election; formulation of community development plan (CDP); funding; implementation; training and decision-making

The dependent variable is sustainability likelihood of Community and Social Development Project (CSDP) in the study area. This was achieved by considering the economic, social, technical and environmental dimensions of sustainability as asserted by Oino, Kirui, Towett and Luvenga (2015) and Mulei and Gachengo (2021)

Economic sustainability likelihood relates to the availability of users' charge; availability of bank account for the maintenance of the project; contribution of fee for project maintenance; insurance of projects; loss of economic sustainability as a result of the projects

Technical sustainability likelihood relates to the preparation of sustainability plan by the community; training community members on the maintenance of the projects; availability of maintenance committee; monitoring of project; supervision of project; use of durable materials; ability to repair projects

Social sustainability likelihood relates to the relevance of the project to community needs; availability of sanctions for project misuse of projects; ownership of projects; compatibility of projects with religious and cultural beliefs and location of projects

Environmental sustainability likelihood relates to the preparation of environmental management plan; assessment of the impact of the project on the environment; effect of the project on natural resources and effect of the project on the environment

Data were analysed using thematic review. The audio-recorded data was transcribed into Microsoft word format and appropriately labeled in accordance to the name of the focus group. These labeled documents were added in software for qualitative analysis which provided a guide for the identification of the focus group as shown below. The data were scrutinized and segmented into themes/codes.

Each coded data is automatically given a quotation which consists of two numbers. For instance, the ID 4:11 means that the quotation comes from the $4^{\text {th }}$ focus group discussion (Ekiti Irasa elderly group) and it is the $11^{\text {th }}$ quotation that was created in $4^{\text {th }}$ focus group discussion document. Patterns and themes from the perspective of the participants were identified, organised categorically, described and explained through figures. Photographs were sorted according to the contexts in which they were taken.

The guide to the quotation identifiers in this study is as follows:

1: ..........Ekiti CSDA IDI

2: ........ Ekiti Irasa adult female FGD

3: ........ Ekiti Irasa adult male FGD

4: ........ Ekiti Irasa elderly FGD

5: ........ Ekiti Irasa youth FGD
6: ........ Ekiti Iwoye Oke Odi adult female FGD

7: ......... Ekiti Iwoye Oke Odi adult male FGD

8: ....... Ekiti Iwoye Oke Odi elderly 
Creative Commons User License: CC BY-NC-ND

Abstracted by: EBSCOhost, Electronic Journals Service (EJS),

Google Scholar, Journal Seek, Scientific Commons,

Food and Agricultural Organization (FAO), CABI and Scopus
Journal of Agricultural Extension

Vol. 26 (1) January, 2022

ISSN(e): 24086851; ISSN(Print); 1119944X

http://journal.aesonnigeria.org

http://www.ajol.info/index.php/jae

Email: editorinchief@aesonnigeria.org

http://eoi.citefactor.org/10.11226/v26i1

\begin{tabular}{|c|c|}
\hline \multicolumn{2}{|c|}{ 15: ...... Oyo Kajola adult male FGD } \\
\hline $16: \ldots \ldots$. & Oyo Kajola elderly FGD \\
\hline $17: \ldots \ldots$. & Oyo Kajola youth FGD \\
\hline $18: \ldots \ldots$. & Oyo Opete adult female FGD \\
\hline : ........ & Oyo Opete adult male FGD \\
\hline \multicolumn{2}{|c|}{ 20: ....... Oyo Opete elderly FGD } \\
\hline to 82 & Pictures from the \\
\hline
\end{tabular}

15: ...... Oyo Kajola adult male FGD

9: ....... Oyo Ayetoro adult female

FGD

Oyo Ayetoro adult male FGD

11: ...... Oyo Ayetoro elderly FGD

12: ...... Oyo Ayetoro youth FGD

13: ...... Oyo CSDA IDI

14: ...... Oyo Kajola adult female FGD

21 to 83

\section{Results and Discussion}

\section{Community Involvement in Community and Social Development Project by Gender and Generation}

Figure $1 \mathrm{a}$ and $1 \mathrm{~b}$ describe the involvement of community members in CSDP. It was reported that the community requested the projects from the Community and Social Development Agency (CSDA) (2:20, 12:1, 19:1 and 6:3). This reflects communitydriven development, an approach that is encouraged by the State Agency (SA). In fact, unless communities indicate their interest in CSDP by writing a letter of interest to the SA, community and social development projects will not be implemented. The members of the different groups also reported that projects were identified and prioritised by the community $(5: 1)$. Projects were also selected by the community (2:54 and 6:5). It was also noted that while some communities assessed the communities (6:4 and 2:3) and drew community map (38:1), Irasa community did not draw community map (2:22).

As part of the activities of CSDP, community members are required to elect the members of Community Project Maintenance Committee (CPMC); while most community members were involved in the election of the members of CPMC (2:7), there was a report that there was no election in a community, hence, no involvement in the election of CPMC (16:5).

Additionally, community members were required to pay the counterpart fund of ten percent $(10 \%)$, which was done while the CPMC bank account was opened as part of the requirement for funding the project $(2: 23,24)$. Furthermore, the formulation of the Community Development Plan (CDP) is the community's responsibility and not that of the CSDA. The CDP is a comprehensive plan on the development activities of the projects to be implemented by the community members specifying what is to be done, how it is to be done, when it is to be done and who is to do what. It was reported that the CDP was prepared by the community (3:3 and 5:8). Also, it was affirmed that the community members were present (3.5) during the project launch. The community took decisions related to the project (7:2, 12:4, 2:30 and 9:2). This means that the approach employed by CSDP manifests genuine involvement.

The community members also implemented the projects $(2: 25,26 ; 3: 6,9: 3$ and $5: 2)$ and community members were trained on certain aspects related to the projects (3:2, 
Creative Commons User License: CC BY-NC-ND

Abstracted by: EBSCOhost, Electronic Journals Service (EJS),

Google Scholar, Journal Seek, Scientific Commons,

Food and Agricultural Organization (FAO), CABI and Scopus

http://eoi.citefactor.org/10.11226/v26i1
Journal of Agricultural Extension Vol. 26 (1) January, 2022

ISSN(e): 24086851; ISSN(Print); 1119944X

http://journal.aesonnigeria.org

http://www.ajol.info/index.php/jae

Email: editorinchief@aesonnigeria.org

$6: 6,2: 29$ and 57:1). The latter finding is in tandem with Ogo-Oluwa (2017) result, which revealed that community members were trained in project management, bookkeeping, community contracting/procurement, participatory monitoring and evaluation, and conflict resolution team building for the enhancement of their capacities. 
Creative Commons User License: CC BY-NC-ND

Abstracted by: EBSCOhost, Electronic Journals Service (EJS),

Google Scholar, Journal Seek, Scientific Commons,

Food and Agricultural Organization (FAO), CABI and Scopus
Journal of Agricultural Extension

Vol. 26 (1) January, 2022

ISSN(e): 24086851; ISSN(Print); 1119944X

http://journal.aesonnigeria.org

http://www.ajol.info/index.php/jae

Email: editorinchief@aesonnigeria.org

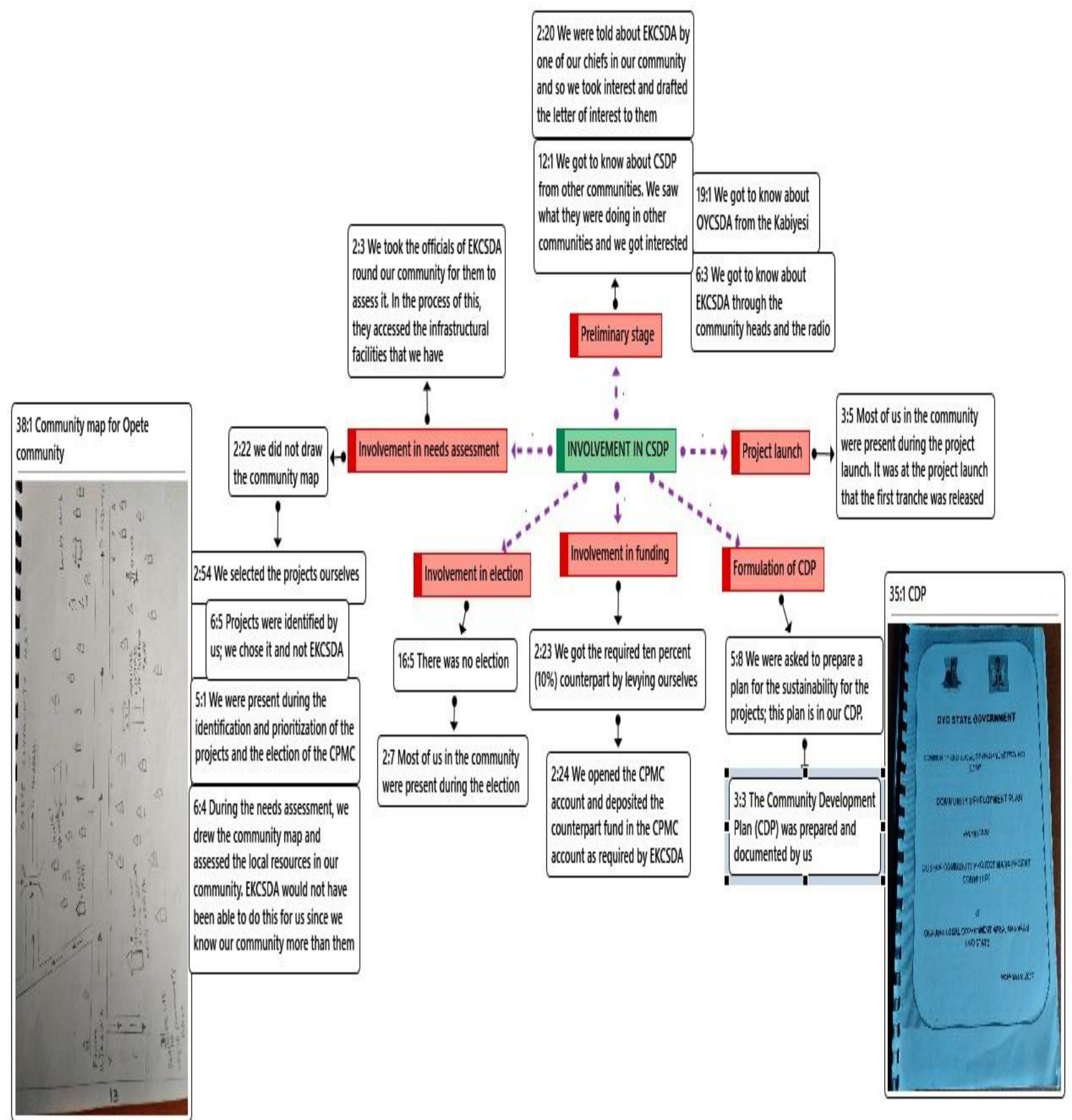

Figure 1a: Gender and generational involvement in CSDP

Source: Field survey, 2019 
Creative Commons User License: CC BY-NC-ND

Abstracted by: EBSCOhost, Electronic Journals Service (EJS),

Google Scholar, Journal Seek, Scientific Commons,

Food and Agricultural Organization (FAO), CABI and Scopus

http://eoi.citefactor.org/10.11226/v26i1
Journal of Agricultural Extension

ISSN(e): 24086851; ISSN(Print); 1119944X

http://journal.aesonnigeria.org

http://www.ajol.info/index.php/jae

Email: editorinchief@aesonnigeria.org

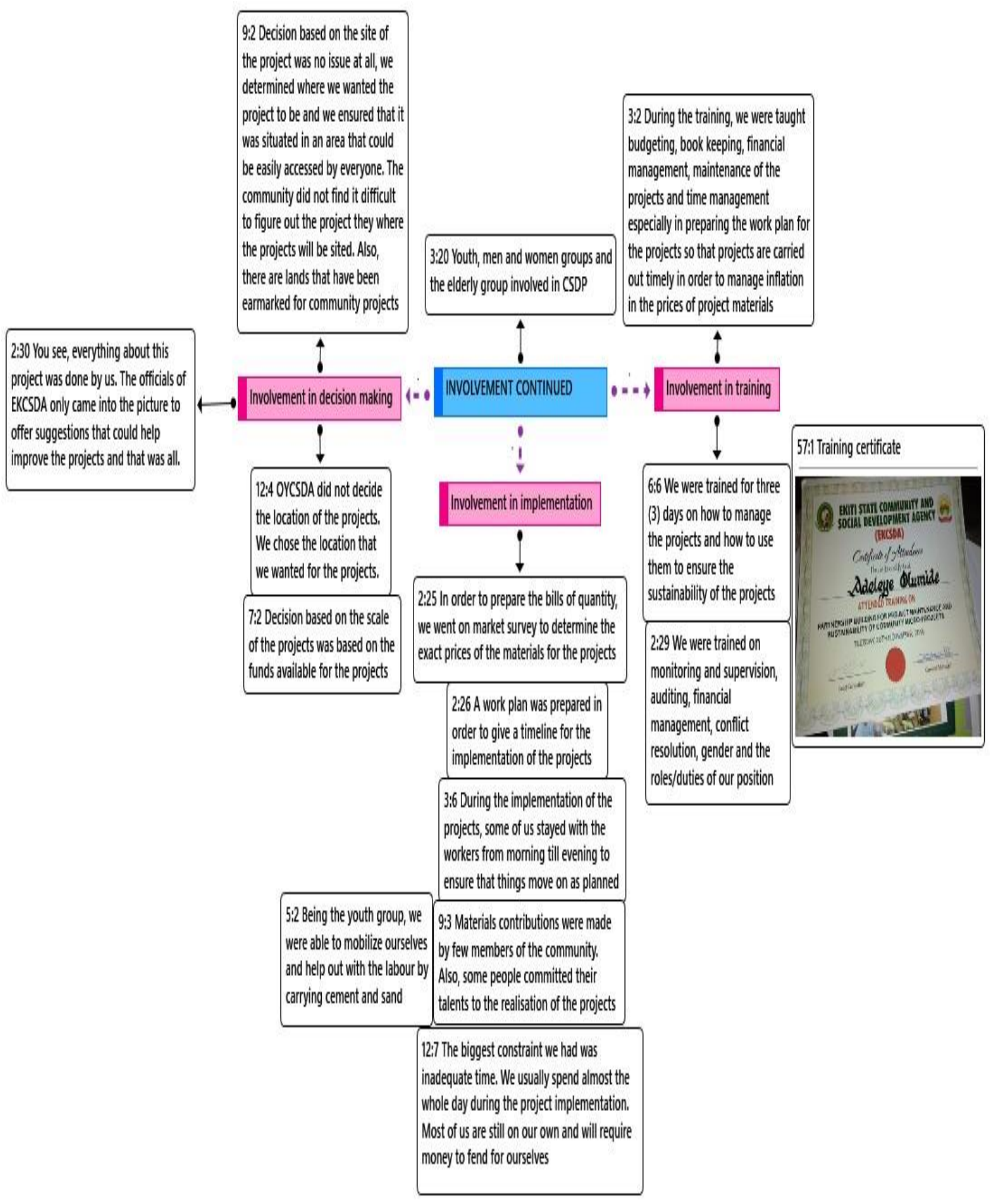

Figure 1b: Involvement in CSDP by gender and generation

Source: Field survey, 2019 


\section{Sustainability Likelihood of Community and Social Development Project}

Figure 2 describes the economic sustainability likelihood of CSDP. It was revealed that none of the projects were insured (19:4, 2:36 and 11:5). This finding reveals the non-compliance of communities to the procurement of services under the insurance section of the project implementation manual of CSDP that projects where applicable must be insured after completion to cover contingencies such as fire, theft and/or acts of God. Similarly, most of the groups indicated that there was no service/users' charge $(4: 12,6: 24,15: 6$ and 16:7) for the maintenance of the projects. Thus, instead of the service/users' charge for the maintenance of projects, most of the communities leverage on contribution (2:33 and 13:9), although, a group indicated that contributions are not made for the maintenance of the project presently (11:4). Also, there were variations in the maintenance of the CPMC bank account; while a group indicated that the CPMC bank account is still being maintained (2:35), there was no maintenance of the bank account in another case (7:6). Based on the availability of funds for the projects, groups expressed the inadequacy of funds $(6: 26,1: 27$ and 5:5). The inadequacy of funds for the maintenance of the projects implies low financial capacity of the community members which is likely to have an impact on the sustainability of project as documented by Mwangangi and Wanyoike (2016) and Kaimenyi and Wanyonyi (2019) that the financial capacity of community members has a strong positive relationship with the sustainability of borehole project.

Figure 3 shows that the technical sustainability likelihood of CSDP focused on the preparation of sustainability plan, monitoring and supervision, repair of projects, cleaning of project sites, maintenance committee, use of projects, security of projects, training of community members, preparation of sustainability plan and durability of materials. The use of durable materials $(2: 40)$ was found to be a fundamental requirement for the sustainability of the projects upon which other activities lie. Hence, it is expected that since durable materials were used for the projects, the frequency of the occurrence of damaged parts of the project is likely to be minimal. It was revealed that there were activities put in place to ensure the sustainability of the projects. For instance, the training of community members (9:10, 2:55 and 58:1), formation of maintenance committee (8:32 and 2:41), preparation of sustainability plan (5:8 and $30: 1)$, monitoring and supervision (5:7 and $50: 1)$, security of projects (8:30 and 16:8) and cleaning of project sites (8:31 and 20:22). This suggests that capacities are built to ensure the sustainability of projects. Specifically, respondents $(9: 10,2: 55$ and 58:1) noted that they were trained to ensure that projects are sustained. This finding is similar to Mwangangi and Wanyoike (2016) finding, which established the importance of training in the sustainability of projects. Furthermore, periodic training of community members (2:55) also ensures continual sharing of skills and the transfer of skills to new 
members of the community. Groups expressed that projects were functional and in use (19:5 and 2:38). Communities also expressed their readiness to repair the projects in case there is a breakdown of the projects $(10.34,6: 10$ and 11). It was also observed that there was no formal structure put in place by the community to ensure the security of projects (8:30 and 16:8). The absence of security over community projects predisposes these projects to theft and vandalism, which impacts the sustainability of projects (Ikejemba and Schuur, 2018). Additionally, the readiness of community members to repair the projects, ensure the security of the projects and the cleaning of projects' sites is an indication of community ownership of the projects, which is likely to result in the continued functionality of the projects

Figure 4 shows the social sustainability likelihood of CSDP. Before implementing the projects, a social impact assessment was carried out to ascertain the appropriateness of the projects (7:7 and 25:1). Projects established were in tandem with the cultural and religious beliefs of the communities, as seen in Figure 4 (2:43 and 19:3). Respondents noted that there were no rules for the distribution of the benefits of the projects that had a discriminatory undertone, as also seen in Figure 4 (3:11 and 16:9). Furthermore, it was also established that the projects were relevant to the needs of the communities (19:7 and 6:12). Projects were also situated in centrally located areas (3:12 and 8:28) for ease of access to the projects. It was also observed that groups expressed ownership of the projects (2:42 and 5:9). Ownership of the projects by the community indicates that the projects will be maintained by the community, which is likely to lead to the sustainability of the projects.

Figure 5 shows the responses of various groups based on the environmental sustainability of CSDP. Respondents indicated that the Environmental Impact Assessment (EIA) was carried out to determine the environmental suitability of the projects (1:34, 2:46, 3:13 and 7:8). It was observed that there was no adverse effect on the natural resources of the environment (5:10 and 7:9) and no negative effect on the environment (2:45, 4:6, 6:13 and 14:5). However, the communities prepared an environmental management plan to guide against any adverse effects on the environment (44:1). 
Abstracted by: EBSCOhost, Electronic Journals Service (EJS), Vol. 26 (1) January, 2022

Google Scholar, Journal Seek, Scientific Commons,

ISSN(e): 24086851; ISSN(Print); 1119944X

Food and Agricultural Organization (FAO), CABI and Scopus

http://journal.aesonnigeria.org

http://www.ajol.info/index.php/jae

http://eoi.citefactor.org/10.11226/v26i1

Email: editorinchief@aesonnigeria.org

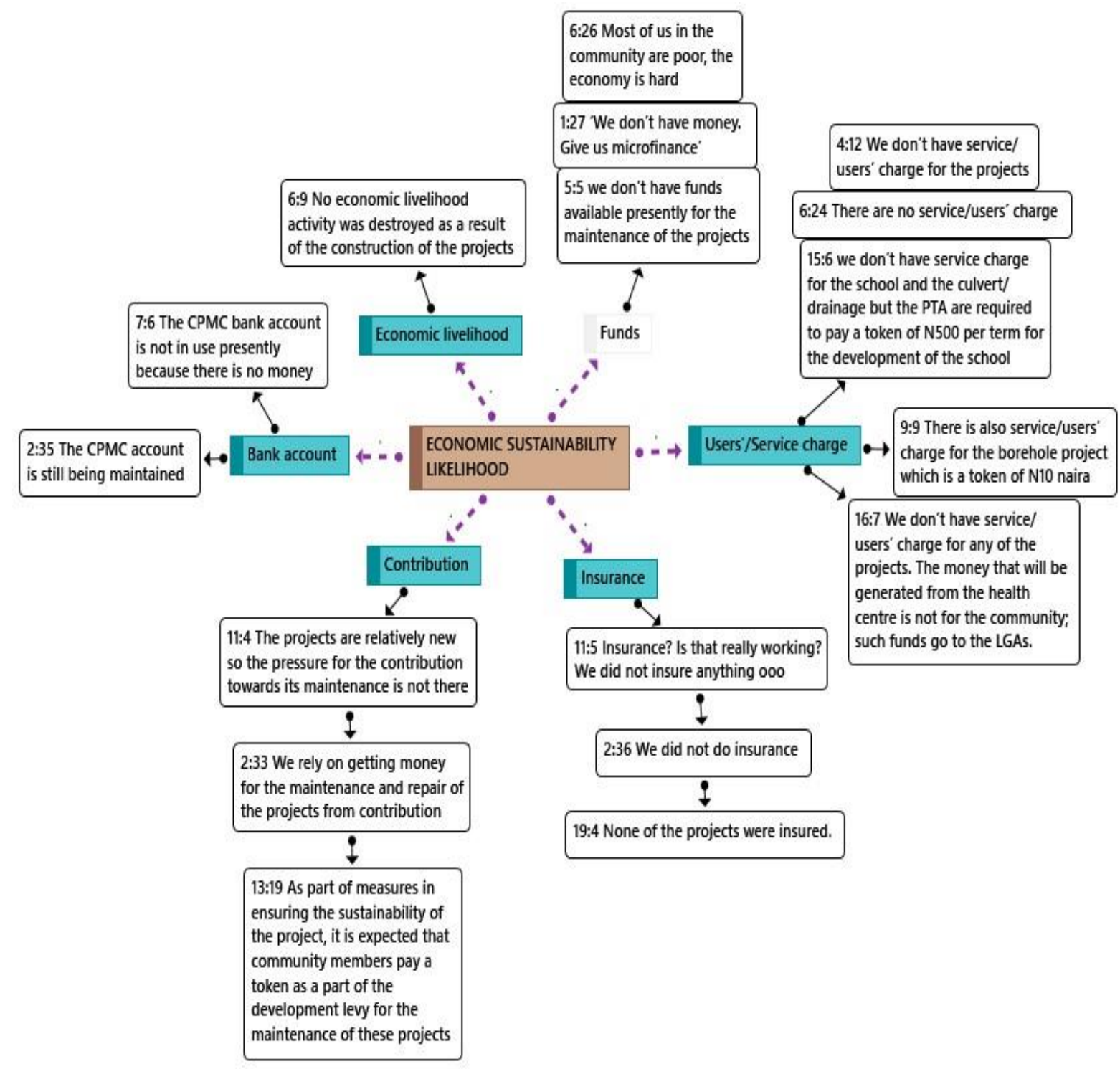

Figure 2: Economic sustainability likelihood of CSDP Source: Field survey, 2019 
Creative Commons User License: CC BY-NC-ND

Abstracted by: EBSCOhost, Electronic Journals Service (EJS),

Google Scholar, Journal Seek, Scientific Commons,

Food and Agricultural Organization (FAO), CABI and Scopus

http://eoi.citefactor.org/10.11226/v26i1
Journal of Agricultural Extension

Vol. 26 (1) January, 2022

ISSN(e): 24086851; ISSN(Print); 1119944X

http://journal.aesonnigeria.org

http://www.ajol.info/index.php/iae

Email: editorinchief@aesonnigeria.org

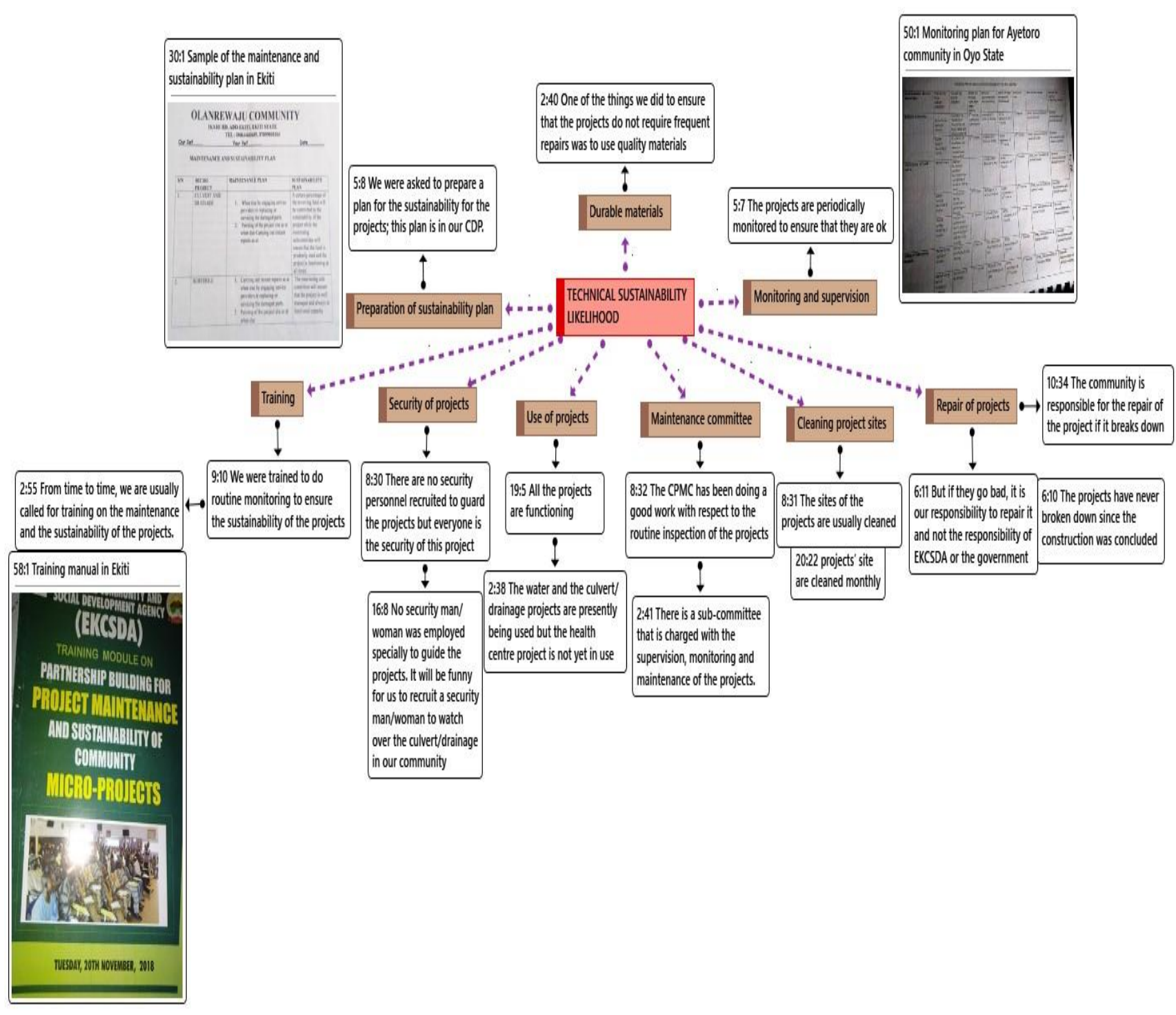

Figure 3: Technical sustainability likelihood of CSDP Source: Field survey, 2019 
Creative Commons User License: CC BY-NC-ND

Abstracted by: EBSCOhost, Electronic Journals Service (EJS),

Google Scholar, Journal Seek, Scientific Commons,

Food and Agricultural Organization (FAO), CABI and Scopus

http://eoi.citefactor.org/10.11226/v26i1
Journal of Agricultural Extension

ISSN(e): 24086851; ISSN(Print); 1119944X

http://journal.aesonnigeria.org

http://www.ajol.info/index.php/iae

Email: editorinchief@aesonnigeria.org

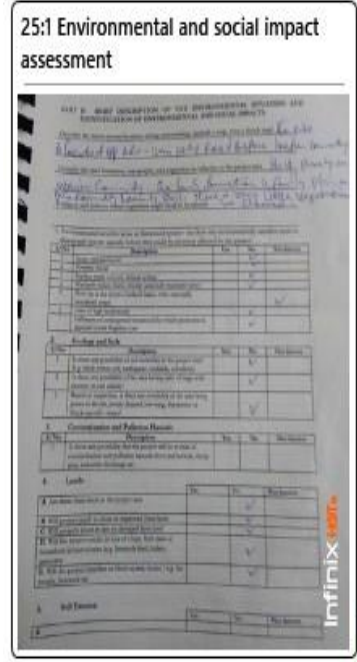

7:7 Social Impact Assessment was carried out by EKCSDA and nothing was left. The result of this is in the CDP

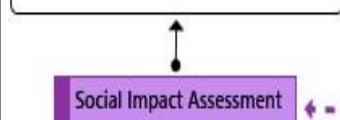

3:11 The distribution of the benefits of the projects is not discriminatory. Anyone can use the projects, we will not say, hey you.... You did not contribute for this project so you can't fetch water

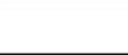

16:9 Anyone can benefit from the projects, we don't say because you are not an indigene of the

community or because you did not contribute towards the

development of the water facility so

you can't fetch water or enroll your children in the community school
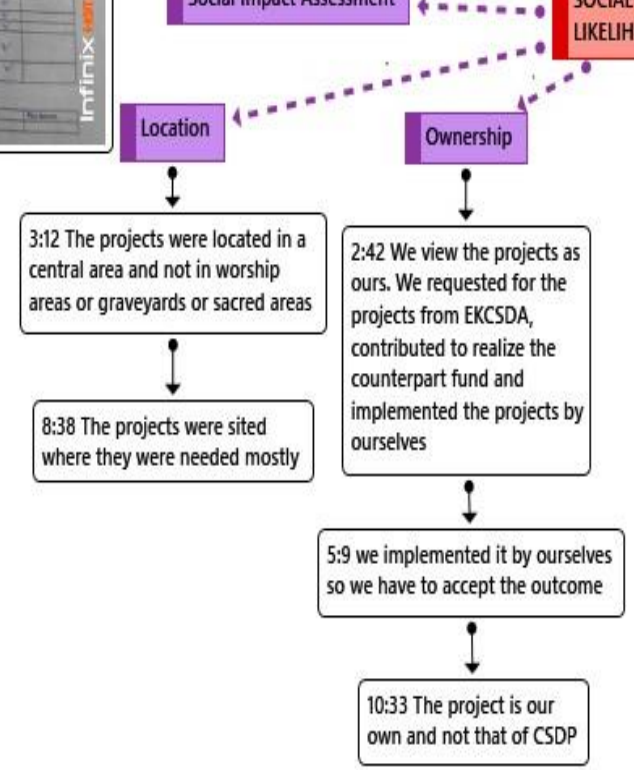
where they were needed mostly
2:43 There is no way that we will choose a project that is not in line with our religious or cultural beliefs. Presently, there is no belief that is being affected by the presence of any of these projects

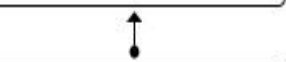

19:3 There is no culture or religious belief that prohibits water, culvert/ drainage and community hall. There are no taboos associated

\section{with the projects}

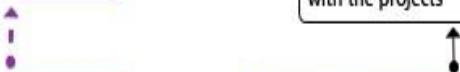

Compatitibility with religious/cultural beliefs

\section{Figure 4: Social sustainability likelihood of CSDP Source: Field survey, 2019}


Creative Commons User License: CC BY-NC-ND

Abstracted by: EBSCOhost, Electronic Journals Service (EJS),

Google Scholar, Journal Seek, Scientific Commons,

Food and Agricultural Organization (FAO), CABI and Scopus

http://eoi.citefactor.org/10.11226/v26i1
Journal of Agricultural Extension

Vol. 26 (1) January, 2022

ISSN(e): 24086851; ISSN(Print); 1119944X

http://journal.aesonnigeria.org

http://www.ajol.info/index.php/jae

Email: editorinchief@aesonnigeria.org

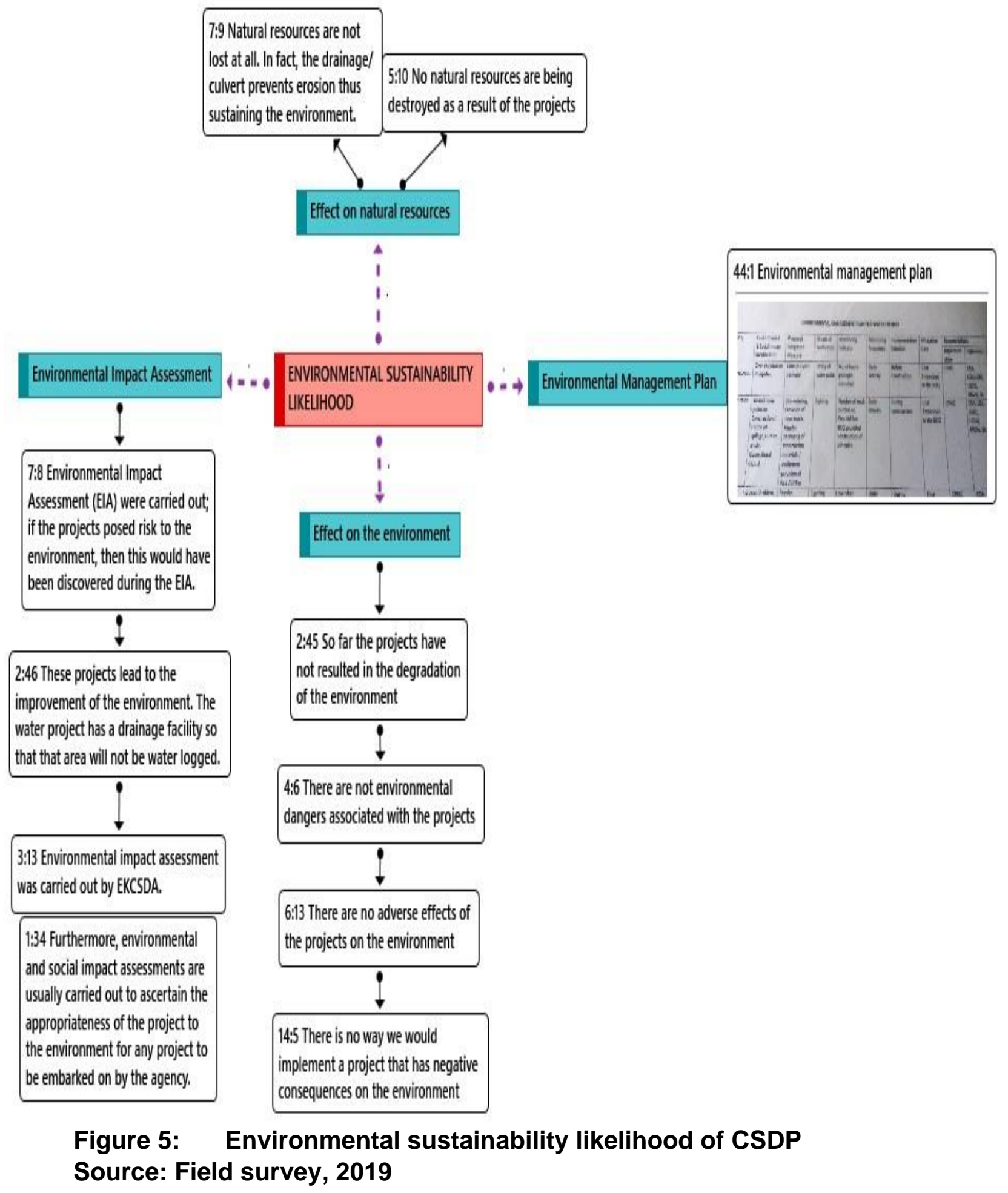


Creative Commons User License: CC BY-NC-ND

Abstracted by: EBSCOhost, Electronic Journals Service (EJS),

Google Scholar, Journal Seek, Scientific Commons,

Food and Agricultural Organization (FAO), CABI and Scopus
Journal of Agricultural Extension

Vol. 26 (1) January, 2022

ISSN(e): 24086851; ISSN(Print); 1119944X

http://journal.aesonnigeria.org

http://www.ajol.info/index.php/jae

Email: editorinchief@aesonnigeria.org

\section{Conclusion and Recommendations}

The youth male and female, adult male and female and elderly male and female groups were involved in the preliminary stage of the project, needs assessment, election, funding, formulation of Community Development Plan (CDP), project launch, decision making, implementation and training. None of the projects were insured. Only one community had service charge. All the projects were functioning and in use. Projects were relevant to the community and environmental impact assessment was carried out.

There was no election of the CPMC in some communities while some communities were either not split at all or not split into the required number of five (5). There should be a monitoring team in the state agency that ensures that the community members comply with the activities required for the implementation of the projects. Additionally, most of the communities indicated that there will be users' charge as part of the sustainability plan. Therefore, the state agency in collaboration with the LGAs should monitor CSDP communities and ensure adherence with the sustainability plan outlined by the communities.

\section{References}

Anderson, B. (2019). Community-driven development: a field perspective on possibilities and limitations. Development Policy Centre Discussion Paper No.82, Crawford School of Public Policy, The Australian National University, Canberra.

Cobbinah, J. E. (2015). Power relations in community participation: Does it really matter? Journal of Economics and Sustainable Development, 6 (13), 144-150

Ikejemba, E. C. X. and Schuur, P. C. (2018). Analysing the impact of theft and vandalism in relation to the sustainability of renewable energy development projects in Sub-Saharan Africa. Sustainability, 10, 1-17. 10.3390/su10030814

Kaimenyi, M. D. and Wanyonyi, L. S. (2019). Factors influencing sustainability of community based County projects in Kenya: A case of Isiolo North Sub County, Isiolo County. International Academic Journal of Information Sciences and Project Management, 3(3), 164-184

Mulei, B. M. and Gachengo, L. (2021). Community Capacity Development and Sustainability of County Government funded water projects in Makueni County. International Academic Journal of Information Sciences and Project Management, 3(6), 419-442

Mwangangi, P. M. and Wanyoike, D. M. (2016). Analysis of factors affecting sustainability of community borehole water projects in Kyuso, Kitui County, Kenya. International Journal of Economics, Commerce and Management, 4(10), 937-971

Ogo-Oluwa, S. O. (2017). Contribution of Community and Social Development Project (CSDP) to project implementation and monitoring in selected LGA Ondo state, Nigeria. Journal of Advances in Management IT and Social Sciences, 7(7), 27-44 
Creative Commons User License: CC BY-NC-ND

Abstracted by: EBSCOhost, Electronic Journals Service (EJS),

Google Scholar, Journal Seek, Scientific Commons,

Food and Agricultural Organization (FAO), CABI and Scopus

http://eoi.citefactor.org/10.11226/v26i1
Journal of Agricultural Extension

Vol. 26 (1) January, 2022

ISSN(e): 24086851; ISSN(Print); 1119944X

http://journal.aesonnigeria.org

http://www.ajol.info/index.php/jae

Email: editorinchief@aesonnigeria.org

Oino, P. G., Towette, G., Kirui, K. K. and Luvenga, C. (2015). The Dilemma in the Sustainability of Community-based Projects in Kenya. Global Journal of Advanced Research, 2(4), 757-768

Rouhani, L. (2017). Unpacking community participation: A gendered perspective. Current Issues in Comparative Education (CICE), 20(1), 33-44.

Wong, S. and Guggenheim, S. (2018). Community-Driven Development: Myths and Realities. Policy Research Working Paper 8435. World Bank Group. 